\title{
Interrelationship between Sustainability Level and Financial Performance of SMEs
}

\author{
Hendri Setyawan \\ Universitas Islam Sultan Agung, Jl. Raya Kaligawe KM 4 Semarang 50112 \\ \{hendri@unissula.ac.id\}
}

\begin{abstract}
SMEs accumulatively contribute greatly to the economy and the environment. However, the attention to the sustainability of SMEs is still considerably low. This study starts from the gap in the results of previous studies. This study aims to examine the effects of financial performance on the sustainability of SMEs and the effects of sustainability of SMEs on their financial performance. The study was conducted at SMEs in the Central Java Province. We used two regression models. A total sample of 300 respondents was obtained. The data used in this study are primary data obtained through questionnaires in August 2019. The results of the study prove that there is no significant influence in either of the two directions above. This proves the validity of the supply and demand hypothesis which states that there is no clear link between the level of sustainability with financial performance
\end{abstract}

Keywords: Please list your keywords in this section.

\section{Introduction}

With the increasing attention to social and environmental problems, the topic of sustainability is increasingly becoming a priority discussion by businesses [1], [2]. The term sustainability itself indicates voluntary activities (by definition) of companies that demonstrate social and environmental care in business operations and in interactions with stakeholders [3].

The notion of sustainability above does not limit the activities of large companies but also includes small and medium enterprises (SMEs). Although smaller in scale than large companies, due to their large numbers, accumulated SMEs have a large impact on the economy and the social and environmental problems that follow [4], [5]. Even so, SMEs generally have limited resources and capabilities compared to large companies [6]. In addition there is a lack of public attention to SMEs from the media [7], the community and the government [8]. As a result, environmentally friendly practices that generally require resources and careful scrutiny of the public receive less encouragement and incentives. Moreover, SME owners/leaders often assume that the impact of environmental problems on SMEs is small [4], [7]. With the above explanation it can be concluded that social and environmental awareness of SMEs in general is still low. This, in turn, increases social and environmental risks that threaten the sustainability of SMEs businesses. 
The concept of sustainability integrates social and environmental objectives with profitseeking goals. Related to that, various sources of literature have linked the relationship between sustainability with financial performance. According to [9] the inclusion of sustainability criteria in business strategies will contribute to the value of the company. Several studies have been conducted to examine the impact of sustainability on finance but the results obtained are not conclusive [10]. Meanwhile, other researchers examined the impact of financial performance on sustainability. They assume that finance is a lubricant for the economy so that it will also affect sustainability. The results obtained by researchers from these relationships are also not conclusive [11]

In addition to the research gap above, studies that have focused on SMEs sustainability have not yet been carried out. This study seeks to fill the research gap to clarify the relationship of sustainability with financial performance. Based on the knowledge gap above, a problem is found, that is "the limited knowledge that explains the effect of financial performance on the sustainability of SMEs and the effect of the sustainability of SMEs on financial performance". Drew on the above problem formulation, the research questions in this study were as follows: 1) How does financial performance influence SMEs' sustainability?; 2) How does sustainability affect SMEs' financial performance?

\section{Literature Review}

\subsection{Concept of Sustainability}

The term sustainability was first introduced by the Bruntland Commission in 1987 as a global concern on environmental damage. The Commission defines sustainable development as meeting current needs without compromising the ability of future generations to meet their own needs [12]). At the organizational level (business) the term sustainability indicates voluntary activities (by definition) of companies that demonstrate social and environmental care in business operations and in interactions with stakeholders [3]. Sustainability emphasizes the balance between earnings and stakeholder needs with environmental protection [6].

\subsection{SME Sustainability}

SMEs have become the backbone of the economy in many countries, so they have a large impact on employment, consumption and also pollution [5]. Even so, SMEs' attention to environmental problems is still lacking. In a study in New Zealand, which is a developed country, SMEs generally pay attention to social issues but do not have a formal report on environmental problems [4]. Attention to the environment generally requires careful public scrutiny, which in this case SMEs get less than large companies [7], [8]. Likewise in terms of resources, large companies certainly have more resources to implement environmentally friendly practices. Meanwhile SMEs do not have that much resources.

\subsection{Relationship of SME Sustainability and Financial Performance}

Several studies have been conducted to examine the impact of sustainability on finance. The social impact hypothesis emphasizes that the higher the CSR the higher the financial performance. This relationship is stated in instrumental theories [13] including the well-known theory of stakeholders theory [14]. These theories consider CSR as a strategic tool for financial gain through competitive advantage [15], increased reputation [16], better brand 
image [17], and higher legitimacy [18]. In this study the level of sustainability is measured using 3 measures, namely in terms of human aspects, economic aspects and environmental aspects.

a) H1a: The higher the level of human aspects of sustainability, the greater the company's financial performance

b) H1b: The higher the level of economical aspect of sustainability, the greater the company's financial performance

c) H1c: The higher the level of environmental aspect of sustainability, the greater the company's financial performance

\subsection{Relationship of Financial Performance and SME Sustainability}

Finance is described as a lubricant for the economy and therefore finance is considered to be able to influence sustainability and corporate social responsibility [11]. According to Rufaro et al [19] SMEs are not only limited in terms of resources and technology but also in terms of finance to fund operations, marketing and budget to fund staff training [20]. This lack of resources can hamper the ability of SMEs to carry out environmentally friendly activities in their operations. The available resources hypothesis states a positive relationship between good financial performance and high levels of CSR. According to Waddock and Graves good financial performance means that money can be invested in CSR so that high profits can be a good indicator of good social outcomes later [21]. The hypotheses in this study are as follows:

a) H2a: The greater the financial performance the greater the level of human aspects of corporate sustainability

b) H2b: The greater the financial performance the greater the level of economic aspects of the corporate sustainability

c) H2c: The greater the financial performance the greater the level of the environmental aspects of corporate sustainability

\section{Research Methods}

\subsection{Population and Sample}

The population in this study is the owner, manager or owner who is also the manager of SMEs in Central Java, which until now the number is not known with certainty. The intended SMEs refers to Law Number 20 of 2008 concerning micro, small and medium enterprises. According to the Law, micro business is a business entity that has a maximum net worth of Rp $50,000,000$, excluding land and buildings for business premises; or those who have annual sales results of at most Rp. 300,000,000. Small Business is a business entity that has a net worth of more than Rp 50,000,000 up to a maximum of Rp 500,000,000 excluding land and buildings where the business is located; or those who have annual sales results of more than Rp. 300,000,000 up to a maximum of $\mathrm{Rp} 2,500,000,000$. While medium business is a business entity that has a net worth of more than $\mathrm{Rp} 500,000,000$ up to a maximum of $\mathrm{Rp}$. $10,000,000,000$ excluding land and buildings for businesses; or those who have annual sales

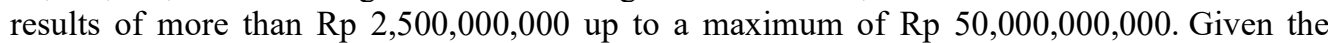
number of SMEs in Central Java is not certain, the researchers tried to use as many samples that are used to statistically represent the population. The questionnaire was submitted by 
officers who had been trained in advance to the SMEs' owners or to people who were entrusted with handling the small business in 10 regencies / cities in Central Java.

\subsection{Data Collection Method}

Because in fact the number of population is not known with certainty, then the method of sampling is done by non-probability sampling. The snowball sampling technique is used to trace the position of prospective research respondents. Through this method, sampling is done by tracing one respondent to another respondent. The survey officer will interview a respondent and ask the respondent for information to show other respondents who can be used as sample members. In this way, the number of respondents will increase accumulatively. This technique was taken because SMEs respondents were widespread in each regency/city and data or information about the address of the small business was very difficult to obtain.

Sampling of research sample members from SMEs uses a purposive sampling method with criteria, (1) respondents have at least 3 years experience because they are considered to have business experience and know the development of company performance, (2) do not have cloud services above 100 people, and (3) willing to provide information. Questions with closed answers on the questionnaire are made using a scale of 1-10 to get interval data and are given a score. Score or value 1 illustrates the scale of strongly disagree on the question or statement submitted, while a score of 10 shows an answer strongly agree with the question or statement. Each respondent is given the broadest opportunity to give a score or a value on a scale of 1-10 in the boxes (cells) provided after the question item is finished, namely at the bottom of each question.

\subsection{Operational Definition and Variable Measurement}

This study uses two variables, namely SMEs` sustainability and financial performance. The operational definition of these variables is obtained from various views of previous researchers. The definition of sustainability and financial performance uses [6] which is based on previous works. Sustainability indicators use measures that can determine the level of sustainability. The operational definition of financial performance is measured using indicators. Financial indicators such as ROA.

\section{Results And Discussion}

\subsection{Results}

This research was conducted at SMEs in the city of Semarang and surrounding areas. A total sample of 300 respondents was obtained. The data used in this study are primary data obtained through questionnaires in August 2019.

a) Model 1

Table 1. Test the Significance of Individual Model 1 Parameters

\begin{tabular}{lcccc}
\hline \multicolumn{4}{c}{ Coefficients $^{\text {a }}$} & \\
\hline Model & $\begin{array}{c}\text { Unstandardized } \\
\text { Coefficients }\end{array}$ & $\begin{array}{c}\text { Standardized } \\
\text { Coefficients }\end{array}$ & t & Sig. \\
\hline
\end{tabular}




\begin{tabular}{|c|c|c|c|c|c|c|}
\hline & & B & Std. Error & Beta & & \\
\hline \multirow{4}{*}{1} & (Constant) & 1,454 & .217 & & 6,685 & .000 \\
\hline & Htot & -.004 & .004 & -.067 & -1.105 & .270 \\
\hline & Etot & .008 & .004 & .110 & 1,900 & .058 \\
\hline & Lt's & -.003 & .006 &,- 028 & -471 & .638 \\
\hline
\end{tabular}

From the SPSS output in the significance column it can be concluded that none of these three variables significantly influence ROA.

b) Model 2a

Table 2. Test the Significance of Individual Model Parameters 2a

\begin{tabular}{llrrrrr}
\hline \multicolumn{7}{c}{ Coefficients ${ }^{\text {a }}$} \\
\hline \multirow{2}{*}{ Model } & \multicolumn{2}{c}{$\begin{array}{c}\text { Unstandardized } \\
\text { Coefficients }\end{array}$} & $\begin{array}{c}\text { Standardized } \\
\text { Coefficients }\end{array}$ & T & Sig. \\
\cline { 2 - 5 } & B & Std. Error & Beta & & \\
\hline \multirow{2}{*}{1} & (Constant) & 37,815 & 1,623 & & 23,295 & .000 \\
& ROA & $-1,250$ & 986 & -.073 & $-1,268$ & .206 \\
\hline \multicolumn{2}{l}{ a. Dependent Variable: Htot } & & & & \\
\hline
\end{tabular}

From the SPSS output in the significance column it can be concluded that the ROA variable does not significantly affect the Human Aspect of Sustainability.

c) Model 2b

Table 3. Test the Significance of Individual Model Parameters $2 b$

\begin{tabular}{|c|c|c|c|c|c|c|}
\hline \multicolumn{7}{|c|}{ Coefficients a } \\
\hline & \multirow[t]{2}{*}{ Model } & \multicolumn{2}{|c|}{$\begin{array}{c}\text { Unstandardized } \\
\text { Coefficients }\end{array}$} & \multirow{2}{*}{$\begin{array}{c}\begin{array}{c}\text { Standardized } \\
\text { Coefficients }\end{array} \\
\text { Beta }\end{array}$} & \multirow[t]{2}{*}{$\mathbf{t}$} & \multirow[t]{2}{*}{ Sig. } \\
\hline & & B & Std. Error & & & \\
\hline \multirow{2}{*}{1} & (Constant) & 39,055 & 1,328 & & 29,412 & .000 \\
\hline & ROA & 1,498 & .806 & .107 & 1857 & .064 \\
\hline
\end{tabular}

From the SPSS output it can be concluded that the ROA variable does not significantly affect the Economical Aspect of Sustainability.

d) Model 2c

Table 4. Test the Significance of Individual Model 2c Parameters

\begin{tabular}{|c|c|c|c|c|c|}
\hline \multicolumn{6}{|c|}{ Coefficients ${ }^{a}$} \\
\hline \multirow[t]{2}{*}{ Model } & \multicolumn{2}{|c|}{$\begin{array}{l}\text { Unstandardized } \\
\text { Coefficients }\end{array}$} & \multirow{2}{*}{$\begin{array}{c}\begin{array}{c}\text { Standardized } \\
\text { Coefficients }\end{array} \\
\text { Beta } \\
\end{array}$} & \multirow[t]{2}{*}{$\mathbf{t}$} & \multirow[t]{2}{*}{ Sig. } \\
\hline & B & Std. Error & & & \\
\hline (Constant) & 19,852 & 1,032 & & 19322 & .000 \\
\hline ROA & -446 & .627 & -.041 & -712 & .477 \\
\hline
\end{tabular}


From the SPSS output it can be concluded that the ROA variable does not significantly affect the Environmental Aspect of Sustainability.

\subsection{Discussion}

In the trade off hypothesis explained that the high social environmental activities of the company led to the low financial performance of the company. Friedman asserts that business activities are solely aimed at profit-making motives without any obligation related to CSR [22]. Investment in environmental social activities will only make it difficult for companies to compete with competitors and result in declining profits. The managerial opportunism hypothesis states that directors act to increase their personal benefits and reduce CSR activities when corporate profits are high. This hypothesis implies the negative influence of financial performance on the level of sustainability [23].

The opposite is stated in the Available resources hypothesis which explains that good financial results can then be used for sustainability activities. Thus there is a positive influence on financial performance on the level of sustainability. Furthermore, some authors argue that the relationship between financial performance and level of sustainability becomes a synergistic positive two-way relationship and a mutually reinforcing cycle. The results showed that the level of sustainability measured using three measures each from human, economic and environmental aspects did not affect the financial performance. The subsequent relationship between financial performance and the three measures of sustainability level also shows no significant effect. This proves another hypothesis, namely the supply and demand hypothesis . This hypothesis emphasizes that there is no clear link between the level of sustainability and financial performance. each company has its own level, which depends on various things such as size, publicity, R\&D, consumer income and market conditions. Their ideal level is determined by a cost-benefit analysis. Thus the relationship between the two variables is said to be neutral.

\section{Conclusion}

This research examines two things. The first is analyzing the impact of the level of sustainability which is measured using three variables, namely (i) human aspects of sustainability, (ii) economic aspects of sustainability (economic aspects of sustainability), (iii) environmental aspects of sustainability ( environmental aspects of sustainability) on financial performance. The second is to analyze the impact of the influence of financial performance on the level of sustainability measured using the three variables above. The results of the study prove that there is no significant influence in either of the two directions above. This proves the validity of the supply and demand hypothesis which states that there is no clear link between the level of sustainability with financial performance. The relationship between the two variables is said to be neutral. Each company has its own ideal level which is determined by cost-benefit analysis. This level depends on size, publicity, R\&D, consumer income and market conditions. Subsequent research can use a broader sample and use other measures of sustainability to prove the effect of the two-way relationship on the level of sustainability and financial performance. 


\section{Refferences}

[1] C. Malesios, A. Skouloudis, P. K. Dey, F. Ben Abdelaziz, A. Kantartzis, and K. Evangelinos, "Impact of small- and medium-sized enterprises sustainability practices and performance on economic growth from a managerial perspective: Modeling considerations and empirical analysis results," Bus. Strateg. Environ., vol. 27, no. 7, pp. 960-972, Nov. 2018.

[2] S. B. Moore and S. L. Manring, "Strategy development in small and medium sized enterprises for sustainability and increased value creation," J. Clean. Prod., vol. 17, no. 2, pp. 276-282, Jan. 2009.

[3] M. van Marrewijk and W. Marco, "Multiple Levels of Corporate Sustainability," J. Bus. Ethics, vol. 44, no. 2-3, pp. 107-119, 2003.

[4] K. P. and M. A. S. R. Lawrence,E. Collins, "Sustainability Practices of SMEs: the Case of NZ," vol. 159, pp. 149-159, 2006.

[5] N. Yadav, K. Gupta, L. Rani, and D. Rawat, "Drivers of Sustainability Practices and SMEs: A Systematic Literature Review,” Eur. J. Sustain. Dev., vol. 7, no. 4, Oct. 2018.

[6] B. Prabawani, "Measuring SMEs' Sustainability: A Literature Review And Agenda For Research," 2013.

[7] E. Masurel, "Why SMEs invest in environmental measures: Sustainability evidence from small and medium-sized printing firms," Bus. Strateg. Environ., vol. 16, no. 3, pp. 190-201, 2007.

[8] C. Belu, "Ranking corporations based on sustainable and socially responsible practices. A data envelopment analysis (dea) approach," Sustain. Dev., vol. 17, no. 4, pp. 257-268, 2009.

[9] P. Aggarwal, "Relationship between Environmental Responsibility and Financial Performance of Firm: A Literature Review," IOSR J. Bus. Manag., vol. 13, no. 1, pp. 13-22, 2013.

[10] M. J. Charlo, I. Moya, and A. M. Muñoz, "Sustainable development and corporate financial performance: A study based on the FTSE4Good IBEX index," Bus. Strateg. Environ., vol. 24, no. 4, pp. 277-288, May 2015.

[11] B. Scholtens, "Finance as a driver of corporate social responsibility," J. Bus. Ethics, vol. 68, no. 1, pp. 19-33, Sep. 2006.

[12] W. Visser and G. H. Brundtland, "Our Common Future ('The Brundtland Report'): World Commission on Environment and Development," Top 50 Sustain. Books, pp. 52-55, 2013.

[13] E. Garriga and D. Melé, "Corporate social responsibility theories: Mapping the territory," Cit. Class. from J. Bus. Ethics Celebr. First Thirty Years Publ., pp. 69-96, 2013.

[14] R. E. Freeman, Management Consulting Editor. 1984.

[15] M. E. Porter and M. R. Kramer, "The competitive advantage of corporate philanthropy," Harv. Bus. Rev., vol. 80, no. 12, p. 57, 2002.

[16] C. Fombrun and M. Shanley, "What's in a Name? Reputation Building and Corporate Strategy," Acad. Manag. J., vol. 33, no. 2, pp. 233-258, 1990.

[17] K. B. Murray and J. R. Montanari, "Strategic Management of the Socially Responsible Firm: Integrating Management and Marketing Theory," Acad. Manag. Rev., vol. 11, no. 4, p. 815, 1986.

[18] S. L. Hart and C. M. Christensen, "The Great Leap: Driving Innovation From the Base 
of the Pyramid," MIT Sloan Management Review 44(1):51-56, 2002.

[19] E. R. T. Chiware and A. L. Dick, "Information needs and information seeking patterns of small, medium and micro enterprises in Namibia," Inf. Dev., vol. 24, no. 1, pp. 24 $36,2008$.

[20] J. M. Jasra, M. A. Khan, A. I. Hunjra, R. A. Ur Rehman, and R. I. Azam, "DETERMINANTS OF BUSINESS SUCCESS OF SMALL AND MEDIUM ENTERPRISES,” Int. J. Bus. Soc. Sci., vol. 2, no. 20, pp. 274-280, 2011.

[21] S. Waddock and S. Graves, "The CSP - CFP link," Bus. Soc., vol. 36, no. 1, pp. 5-31, 1997.

[22] M. Friedman, "The social responsibility of business is to increase its profits," Corp. Soc. Responsib., pp. 31-35, 2017.

[23] P. Douglas and O. Bannon, "Preston1997," Bus. Soc., vol. 36, no. 4, pp. 419-429, 1997. 